\title{
An Exploration to the Factors Affecting China's Mergers and Acquisitions Costs
}

\author{
Ting Chen \\ Macau University of Science and Technology, Macau
}

\author{
Xia Pan \\ Clark University, USA
}

\begin{abstract}
This article is an exploratory study. We explore and discuss the influencing factors that affect the merger and acquisition (M\&A). We analysis and comment the valuation in the M\&A process, and whether it is worth to do the M\&A. We first introduce the topic and research motivation and methods. Then we introduce the process and realization of $M \& A$, and how to evaluate the M\&A. Further, we talk about the influence factors in $M \& A$, not only in the financial way, but in a broader market ken. In the last, we make suggestions on how to reduce the risk for a successful M\&A.
\end{abstract}

Keywords: Merger \& Acquisition, M\&A synergy, Chinese financial market, M\&A risk evaluation

\section{INTRODUCTION}

The term M\&A refers to the department at financial institutions that deals with Merger and acquisition. M\&A and corporate restructuring are a big part of the corporate finance world. Every day, Wall Street investment bankers arrange M\&A transactions, which bring separate companies together to form larger ones. When they're not creating big companies from smaller ones, corporate finance deals do the reverse and break up companies through spin-offs, carveours or tracking stocks.

Not surprisingly, these actions often make the news. Deals can be worth hundreds of millions, or even billions, of dollars. They can dictate the fortunes of the companies involved for years to come. For a CEO, leading an M\&A can represent the highlight of a whole career. And it is no wonder we hear about so many of these transactions; they happen all the time. Next time you flip open the newspaper's business section, odds are good that at least one headline will announce some kind of M\&A transaction.

Naturally, both sides of an M\&A deal will have different ideas about the worth of a target company: its seller will tend to value the company at as high of a price as possible, while the buyer will try to get the lowest price that he can. 


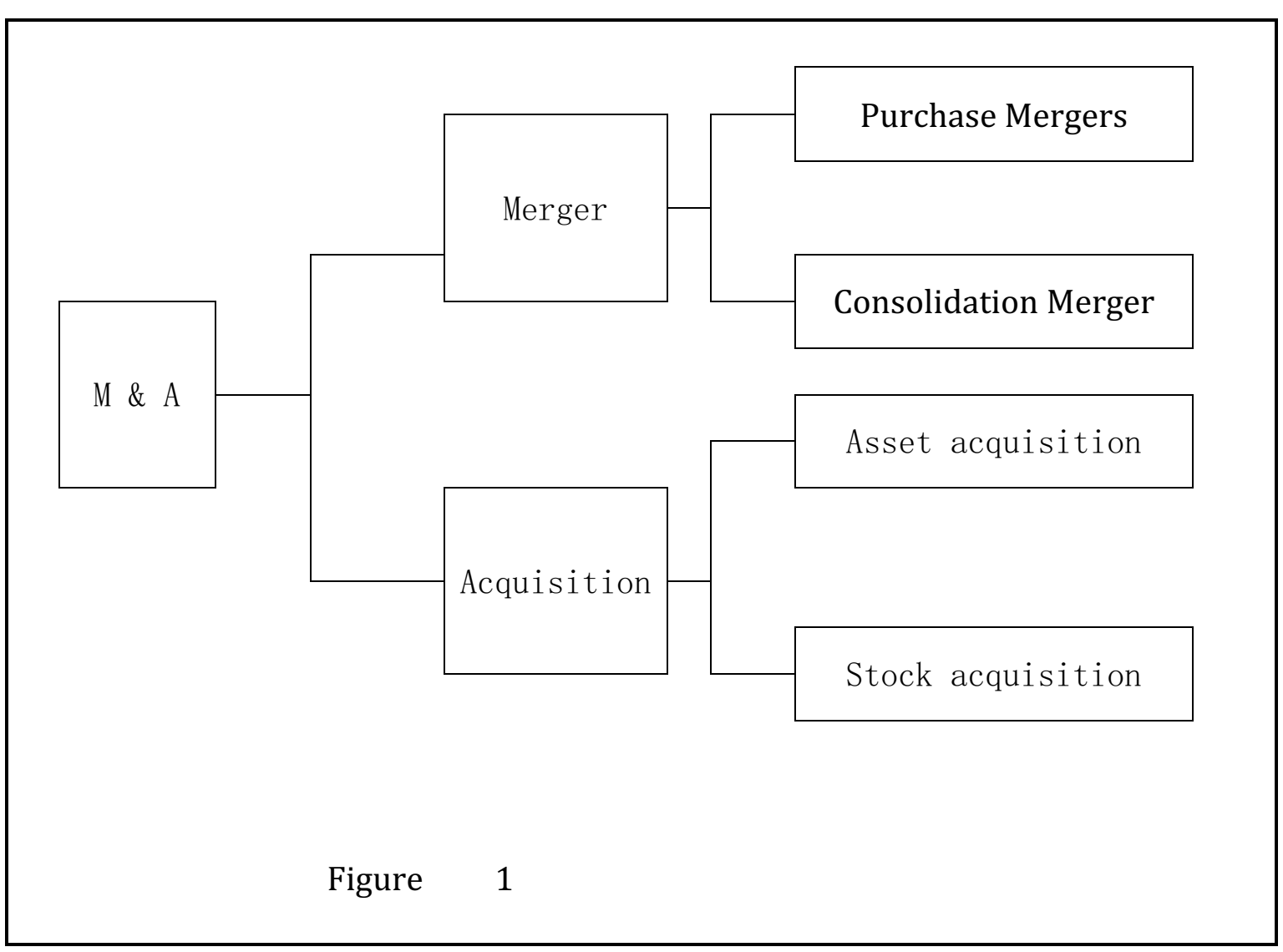

Acquisition is when one company purchases a majority interest in the acquired. A general term used to refer to the consolidation of companies. Acquisitions are actions through which companies seek economies of scale, efficiencies and enhanced market visibility, all acquisitions involve one firm purchasing another - there is no exchange of stock or consolidation as a new company. Acquisitions are often congenial, and all parties feel satisfied with the deal. Other times, acquisitions are more hostile.

In an acquisition, a company can buy another company with cash, stock or a combination of the two. Another possibility, which is common in smaller deals, is for one company to acquire all the assets of another company. Company X buys all of Company Y's assets for cash, which means that Company $\mathrm{Y}$ will have only cash (and debt, if they had debt before). Of course, Company $\mathrm{Y}$ becomes merely a shell and will eventually liquidate or enter another area of business.

Another type of acquisition is a reverse merger, a deal that enables a private company to get publicly-listed in a relatively short time period. A reverse merger occurs when a private company that has strong prospects and is eager to raise financing buys a publicly-listed shell company, usually one with no business and limited assets. The private company reverse merges into the public company, and together they become an entirely new public corporation with tradable shares. Acquisitions can be either friendly or unfriendly. Friendly acquisitions occur when the target firm agrees to be acquired; unfriendly acquisitions don't have the same agreement from the target firm. Following is about the cases different from friendly and unfriendly acquisitions

\section{Case 1: Friendly Acquisition}

Let's talk about the case of friendly acquisition:

On $30^{\text {th }}$, June of 2006, the Allyes and China online game advertising MaeketAllyes and SA20.com agree on strategy cooperation. The Sa20.com is the game top 2 portal website, 
Sa20.com is a leading online game Chinese internet media all over the world, was the largest Chinese players' residence for cartoon online game "Stone Age", and also is one of the largest portal websites in the online game industry.

On $20^{\text {th }}$, June , Allyes and China online willing to be the partner. SA20.com will be the only advertising sales agency of Allyes' Smart Trade media platform in the game industry. Online game is very popular in China these years, particularly the young people, about 15-35 in age, like playing online game very much. For example, QQ games, world of warcraft, everybody knows of it. Online game has just developed for only 7 years in China, but with a fast speed. According to the official data, Chinese internet users have been 111,000,000 among which $40,000,000$ are online game players till $31^{\text {st }}$, Dec of 2005; in 2005 online game market has been $\$ 4,070,000,000 \mathrm{RMB}$, and keeps on an increase of over $50 \%$ per year. As the top one online advertising agency in China, Allyes has noted this development since long ago. The cooperation of this time will be an integration of both advantages, and bring more opportunities for the promotion and development of online game industry.

SmartTrade is managed and operated by Allyes Advertising-Network as the largest online advertising league in China. It also has the honor that it won "Top one Advertising League" in the 2005 internet top 100 awards, which held by Chinese internet Associations. Since it is founded in 2004, for 2 years SmartTrade has fast developed to be a super-size advertising platform which attracts over 5,000 hot websites to join in and broadcasts advertisements over $400,000,000$ times per day for advertisers. In the past few years, SmartTrade has successfully promoted the games for the listed fame operation companies in China, received good effects in the online game adverting market.

For this cooperation, Allyes CEO has full confidence that they would succeed and get the big net profit.

\section{Case 2: Unfriendly Acquisition}

Sina is a very famous company in China, its web-site is very popular in society, Shunda is also a very big media company. In 2005, an event happened. On 18 ${ }^{\text {th }}$ Feb of 2005, Shunda (NASDAQ: SNDA) take an action to M\&A Sina (NASDAQ : SINA), purchase $19.5 \%$ stock of the whole company, be the biggest shareholder in Sina. This project was been thought friendly acquisition.

In the same time, the management of Sina publish that, they adopted an idea, work out a plan is "shareholder buying stock plan" in finance called "a noxious plan", to protect all the shareholders' benefit. In the plan, every shareholder on the record (7th March on 2005) without owe the common stock, they will get one more buying stock right. During this period, the right only by deputy the common stock's shareholder, they could not sell it by their selves; the other shareholder could not use this right.

How can use this right? When on person or one party own up to $10 \%$ Sina common stock, or make an agreement with the acquisition of Sina , these right could been used. The shareholder will allowed buying the extra common stock. SNDA and the partner have already own 10\% common stock, this plan allowed them buy the SINA common stock no more than $0.5 \%$.

In the usual time, SINA can atone for buying right in 0.001 US dollar per share. If SINA have been acquisition in future, the owners have the right to buy the stock with the half price. Every price is 150 US dollar 
SINA make a detail plan on the (www.sec.gov), the publics could check the detail on it.

This case is must be written in the M\&A history of China, it the first case in term of American law, it means that Chinese companies will do M\&A more and more normal. Most countries pay attention to this case.

Although there are many ways of structuring an acquisition, there are only three basic forms an acquisition can take: 1 . an asset acquisition, 2 . a stock acquisition, and 3. a merger.

In an asset purchase transaction, the buyer purchases all or substantially all of the seller's assets in exchange for cash, note, or other property. The principal advantage in structuring a transaction as an asset purchase is that the buyer can specify those assets that it will acquire and those liabilities that it will assume. Furthermore, the asset acquisition strategy might be pursued if the acquirer is interested in certain specific assets, and not al the possible target assets.

The buyer may choose to avoid certain know liabilities such as known environmental liabilities, tax liabilities, pending or threatened litigation, and unfavorable contractual obligations.

In a stock purchase transaction, the buyer purchases all, or at least a majority, of the outstanding stock of the seller from its shareholders in exchange for cash, promissory notes, or other property.

Merger is a state law process by which all of the assets and liabilities of the target company are automatically transferred to the surviving company by operation of law.

\section{MERGER}

A merger is a combination of two companies to form a new company,

From the perspective of business structures, there is a whole host of different mergers. Here are a few types, distinguished by the relationship between the two companies that are merging:

1. Horizontal merger, 2. Vertical merger, 3. Market-extension merger, 4. Product-extension merger, 5.Conglomeration

1. Horizontal merger, two companies that are in direct competition and share the same product lines and markets.

2. Vertical merger, a customer and company or a supplier and company. Think of a cone supplier merging with an ice cream maker.

3. Market-extension merger, two companies that sell the same products in different markets.

4. Product-extension merger, two companies selling different but related products in the same market.

5. Conglomeration, two companies that have no common business areas.

There are two types of mergers that are distinguished by how the merger is financed. Each has certain implications for the companies involved and for investors:

1. Purchase Mergers, as the name suggests, this kind of merger occurs when one company purchases another. The purchase is made with cash or through the issue of some kind of debt instrument; the sale is taxable. Acquiring companies often prefer this type of merger because it can provide them with a tax benefit. Acquired assets can be written- 
up to the actual purchase price, and the difference between the book value and the purchase price of the assets can depreciate annually, reducing taxes payable by the acquiring company.

2. Consolidation Mergers, with this merger, a brand new company is formed and both companies are bought and combined under the new entity. The tax terms are the same as those of a purchase merger. Investors in a company that are aiming to tale over another one must determine whether the purchase will be beneficial to them. In order to do so, they must ask themselves how much the company being acquired is really worth.

One plus one makes three: this equation is the special alchemy of a merger or an acquisition. The key principle behind buying a company is to create shareholder value over and above that of the sum of the two companies. Two companies together are more valuable than two separate companies - at least, that's the reasoning behind M\&A.

This rationale is particularly alluring to companies when times are tough. Strong companies will act to buy other companies to create a more competitive, cost-efficient company. The companies will come together hoping to gain a greater market share or to achieve greater efficiency. Because of these potential benefits, target companies will often agree to be purchased when they know they cannot survive alone.

Although they are often uttered in the same breath and used as though they were synonymous, the terms merger and acquisition mean slightly different things.

In practice, however, actual mergers of equals don't happen very often. Usually, one company will buy another and, as part of the deal's terms, simply allow the acquired firm to proclaim that the action is a merger of equals, even if it's technically an acquisition. Being bought out often carries negative connotations, therefore, by describing the deal as a merger, deal makers and top managers try to make the takeover more palatable.

A purchase deal will also be called a merger when both CEO agree that joining together is in the best interest of both of their companies. But when the deal is unfriendly - that is, when the target company does not want to be purchased - it is always regarded as an acquisition.

Whether a purchase is considered a merger or an acquisition really depends on whether the purchase is friendly or hostile and how it is announced. In other words, the real difference lies in how the purchase is communicated to and received by the target company's board of directors, employees and shareholders.

\section{M\&A PROCESS}

Corporate Strategic Planning and the M\&A Process

Step 1. : Thinking through strategic objectives

Step 2. : Assessing structural capacity

Step 3. : Identifying and screening potential acquisition targets

Step 4. : Performing due diligence

Step 5. : Valuing the acquisition target

Step 6. : Selecting the appropriate legal and structures for the transaction

Step 7. : Managing the integration

Step 8. : Monitoring progress through acquisition scorecarding

Step 9. : Implementing and acquisition feedback loop 
Let's see the process step by step

\section{Step 1.}

Thinking through strategic objectives is very importance; Chinese has the adage: good opening is half a part of success. The CEOs must select the clear target and then make their choice. The foundation of the entire merger and acquisition process is predicated on the clear articulation of the company's underlying corporate strategy. Accordingly, the strategy formulated in Step 1 will significantly impact each subsequent step in the acquisition process

Industries are more or less attractive based on five characteristics:

1. Degree of rivalry in the industry

2. The threat of substitute

3. Barriers to entry

4. Supplier power

5. Buyer's power

\section{Step 2. Assessing structural capacity}

In Step 1, corporate executives are provided with tools that will assist them in articulating an overall corporate strategy. One of the frameworks suggested to help in this process, the SWOT analysis, focuses attention on external factors as well as a self-assessment. This internal analysis is performed at a strategic level during this initial step.

Step 2 extends this process down to more operational level. This step is basically a due diligence investigation that a potential acquiring company should perform on itself. It's based on the premise that a company must first look inward and evaluate its own strengths and weaknesses. Only then will it know if it has the ability and capacity to pursue a strategy of corporate growth through acquisition.

\section{Figure 2}

Four key components of assessing structural capacity or criteria for team readiness for the merger and acquisition process 


\begin{tabular}{|l|l|l|l|}
\hline \multicolumn{1}{|c|}{ Strategic } & \multicolumn{1}{|c|}{ Financial } & \multicolumn{1}{|c|}{ Legal } & Operational \\
\hline $\begin{array}{l}\text {-Understand } \\
\text { macro } \\
\text { variables }\end{array}$ & $\begin{array}{l}\text {-Ensure target } \\
\text { financial } \\
\text { statement } \\
\text { accuracy }\end{array}$ & $\begin{array}{l}\text {-Consider antitrust } \\
\text { issues }\end{array}$ & $\begin{array}{l}\text {-Audit culture } \\
\text { and morale }\end{array}$ \\
\hline $\begin{array}{l}\text {-Understand } \\
\text { market trends }\end{array}$ & $\begin{array}{l}\text {-Perform } \\
\text { sanity check } \\
\text { projections }\end{array}$ & $\begin{array}{l}\text {-Ensure tax } \\
\text { compliance }\end{array}$ & $\begin{array}{l}\text {-Constantly } \\
\text { review } \\
\text { management } \\
\text { team } \\
\text { qualifications }\end{array}$ \\
\hline $\begin{array}{l}\text {-Understand } \\
\text { competitors }\end{array}$ & $\begin{array}{l}\text {-Understand } \\
\text { tax issues }\end{array}$ & $\begin{array}{l}\text {-Review } \\
\text { environmental } \\
\text { liabilities }\end{array}$ & $\begin{array}{l}\text {-Review } \\
\text { production } \\
\text { processes }\end{array}$ \\
\hline $\begin{array}{l}\text {-Understand } \\
\text { target } \\
\text { company } \\
\text { positioning }\end{array}$ & $\begin{array}{l}\text {-Value the } \\
\text { target }\end{array}$ & $\begin{array}{l}\text {-Review key } \\
\text { contracts }\end{array}$ & $\begin{array}{l}\text {-Audit } \\
\text { information } \\
\text { management }\end{array}$ \\
\hline $\begin{array}{l}\text {-Ensure } \\
\text { strategic fit }\end{array}$ & $\begin{array}{l}\text {-Recommend } \\
\text { appropriate } \\
\text { financing }\end{array}$ & $\begin{array}{l}\text {-Review } \\
\text { labor/employment } \\
\text { issues }\end{array}$ & $\begin{array}{l}\text { Audit research } \\
\text { and } \\
\text { development }\end{array}$ \\
\hline
\end{tabular}

Figure 2

Four key activities the finance team must perform during the acquisition process

\section{Corporate Finance}

-Review current capital structure

-Assess fit of capital structure and strategic objectives

-Develop appropriate financing approach

-Manage relationship with financial institutions

\section{Tax Strategy}

-Ensure local, state, and federal tax compliance

-Develop tax optimization strategy for deal structure

-Ensure effective use of NOL, if any exist

\section{Audit}

-Ensure accuracy of financial reporting

-Assess competence of target's financial management team

-Monitor financial due diligence

-Assess adequacy of financial controls

\section{Cash Management}

-Analyze cash requirements of deal

-Assess adequacy of cash reserves

-Manage investment of excess cash

-Assess adequacy of target's treasury management systems

To assess a company's financial ability and capacity to undertake a corporate acquisition program, the financial statement of the company and other relevant operating data are analyzed with the aid of special interpretive tools. 
The four tests that are relevant in determining financial strength in this context are:

1. Asset and liability quality assessment, which examines the strength of the company's existing assets and liabilities

2. Liquidity assessment, which measures the company's ability to meet its current obligations using its cash and currents assets.

3. Solvency assessment, which determines the company's ability to meet long-term debt obligations.

4. Leveragability assessment, which determines the company's capacity for leverage as part of a corporate acquisition strategy.

\section{Step 3. Identifying and screening potential acquisition targets}

This section offers guidelines for establishing a practical search and screen program to uncover acquisition opportunities.

\section{Step 4. Performing due diligence}

The objective of performing due diligence is to uncover and analyze all issues that are likely to impact the success and cost of the acquisition. These issues rang from highly objective, such as whether the accounting statements of the target company are accurate, to the highly subjective, such as whether to organizational cultures of the acquiring and target companies can be successfully integrated. The results of the due diligence investigation are critical in assessing the value of the value of the target company and the potential viability of the merger.

\section{Step 5. Valuing the acquisition target}

This step emphasizes the need to determine a realistic value of the benefits that will accrue to the newly formed entity, which are attributable to what is called "synergistic value". It is hard enough to realistically analyze all the potential synergies that could be achieved in a particular M\&A deal; however, one also must realize that in order to take advantage of those potential synergies, significant costs may be involved. These costs are above and beyond the actual cost of purchasing the acquired company.

\section{Step 6. Selecting the appropriate legal and structures for the transaction}

This step provides an overview of the legal, tax, and regulatory issues that arise most often in merger and acquisition transactions. Due to the complexity of these issues, attorneys and accountants with expertise in corporate, securities, tax, and other regulatory issues must be recruited as part of the acquisition team in order to understand each of the relevant issues and their interplay with the strategic objectives in pursuing the acquisition. As a result, this step surveys the landscape of the legal issues without suggesting the appropriateness of any legal or tax structure for any particular type of transaction.

\section{Step 7. Managing the integration}

Up until now, much of the M\&A strategy guide has focused on the technical side of the transaction, which includes financial, legal, and operational issues.

This step addresses what might be called the political side of the transaction. Political issues include the intangibles of culture, communications, and leadership. Financial or operational problems can be diagnosed and technical solutions for them can be found in a relatively straightforward manner.

Political issues must be dealt with on a grand scale during M\&A integrations. Merger and acquisitions means more people working together. And where there are more people, there are more political issues that must be deal with. It's bad enough if the political aspects of an 
organization are ignored during stable times, but serious damage can be caused if not enough attention is paid to them during major change initiatives such as M\&A integrations. When executives are too busy handling technical issues to attend to political issues, the process usually falls apart. It is exactly at such times of massive change when employees are looking for leadership.

\section{Step 8. Monitoring progress through acquisition scorecarding}

Scorecarding can be a very complex undertaking. However, an acquisition scorecard could prove vital in saving an M\&A transaction that was based on flawed assumptions.

\section{Step 9. Implementing and acquisition feedback loop}

Whereas the acquisition scorecard helps keep executives abreast of progress on any given acquisition, the acquisition feedback loop helps organize ongoing learning, which can be applied to future acquisitions. The finding from which are then fed into a repository of best practices information that can be used for planning and integration of subsequent acquisitions.

\section{THE FACTORS TO REALIZE THE ACQUISITION}

1. The shareholders request of the profit increasing, compare the company's real profit increase range. It must definition of acquisition criteria and organization of the search team

\section{a. Definition of acquisition criteria}

Any search and screen program begins with a broad set of acquisition criteria that fit the strategic and financial goals of the corporate acquisition program. This exercise is an extension of the corporate strategic planning process. The following are some of the factors to be considered;

1) Characteristics of the target company and its industry

2) Size and growth rate of the target company's market

3) Market share and competitive position of the target company within its market

4) Defensible position of the target company within its market

5) Revenue, earnings, and cash flow history of the target company

6) Balance sheet strength of the target company

7) Strength of the target company's intellectual property

8) Investment to be made in the target company and required rates of return

\section{b. Organization of the search team}

The search team is including inside team and outside team.

The inside team should consist of a core group of multidisciplinary professionals from with the acquiring company with backgrounds in business development, finance, operations, law, and accounting. In a large company, the inside team is typically based out of the corporate development department, which maintains various internal technical models for evaluation and structuring acquisitions and has access to external databases which may be useful in identifying possible target companies. The inside team is often best equipped to identify potential acquisitions targets because its members have industry contacts, familiarity with industry dynamics, knowledge of customers and suppliers, and understanding of the competitive strengths and weakness of potential targets.

An outside team of intermediaries, investment bankers, attorneys, accountants, and consultants can supplement the inside team by helping to identify candidates for acquisition 
and by bring a range of professional expertise to bear on the investigation and evaluation of a potential target.

\section{c. Ranking of potential acquisition targets./L $\backslash$}

Having identified potential acquisition targets, the inside team must then assess how well and to what extent the potential targets fit the underlying acquisition criteria, and should rank the targets by the degree of fit. Some acquiring companies use detailed fit charts and points systems to aid in the process of ranking target companies. These methodologies will eliminate a vast majority of the potential targets as inadequate fits.

\section{d. Contacting potential acquisition target}

The fifth phase of the search and screen process is to develop a strategy for contacting the potential acquisition targets. The contact should be made by an intermediary or a representative of the buyer through a letter addressed to the management of the target company.

\section{e. It's restricted by government's law}

Every government of the countries will set the relative law or the policy, such as environment protection, to protect the society, it's good for people, maybe it will restrict in M\&A movements.

Regardless of their category or structure, all mergers and acquisitions have one common goal: they are all meant to create synergy that makes the value of the combined companies greater than the sum of the two parts. The success of a merger or acquisition depends on whether this synergy is achieved

\section{SYNERGY}

Synergy is the magic force that allows for enhanced cost efficiencies of the new business. Synergy takes the form of revenue enhancement and cost savings. By merging, the companies hope to benefit from the following:

1. Staff reductions - As every employee knows, mergers tend to mean job losses. Consider all the money saved from reducing the number of staff members from accounting, marketing and other departments. Job cuts will also include the former CEO, who typically leaves with a compensation package.

2. Economies of scale: Yes, size matters. Whether it's purchasing stationery or a new corporate IT system, a bigger company placing the orders can save more on costs. Mergers also translate into improved purchasing power to buy equipment or office supplies - when placing larger orders, companies have a greater ability to negotiate prices with their suppliers. I will express this point in detail in chapter 4.

3. Acquiring new technology - To stay competitive, companies need to stay on top of technological developments and their business applications. By buying a smaller company with unique technologies, a large company can maintain or develop a competitive edge.

4. Improved market reach and industry visibility - Companies buy companies to reach new markets and grow revenues and earnings. A merge may expand two companies' marketing and distribution, giving them new sales opportunities. A merger can also improve a company's standing in the investment community: bigger firms often have an easier time raising capital than smaller ones.

That said, achieving synergy is easier said than done - it is not automatically realized once two companies merge. Sure, there ought to be economies of scale when two businesses are 
combined, but sometimes a merger does just the opposite. In many cases, one and one add up to less than two.

Sadly, synergy opportunities may exist only in the minds of the corporate leaders and the deal makers. Where there is no value to be created, the CEO and investment bankers - who have much to gain from a successful M\&A deal - will try to create an image of enhanced value. The market, however, eventually sees through this and penalizes the company by assigning it a discounted share price. We'll talk more about why M\&A may fail in a later section of this tutorial.

\section{M\&A VALUATION}

Valuation must be related to the economic and strategic factors affecting business firms. To facilitate consideration of these broader influences that are involved in making valuations, it is necessary to focus on the industry in which the acquisition transaction takes place.

The valuation is divide into two parts: the tangible asset (for example: plant, machinery, real estates, natural resources), and the intangible asset (for example: brand, business, option and other financial instrument). Although any part will be value, it's more or less depending on the CEO's favors.

\section{Market approach}

\section{VALUATION METHODOLOGIES}

It's applied assuming sale of the property in its existing state with the benefit of immediate vacant possession and by making reference to comparable sale transactions as available in the relevant market.

\section{Cost approach}

Depreciate Replacement Cost (DRC) is the current cost of replacement (reproduction) of a property less deductions for physical deterioration and all relevant forms of obsolescence and optimization. DRC requites a valuation of the market value of the land in its existing use and an estimate of the depreciated replacement cost of the building.

\section{Investment approach}

This method rests on the assumption that the capital value of an interest in the property is directly related to the income or annual value of the property. This approach operates by taking into account the net rental incomes of the properties ( annual gross income net of operating expenses) derived from the existing tenancies with due allowance for the reversionary income potential of the tenancies, which are then capitalized into the values are appropriate capitalization rates.

\section{Residual method}

This method of valuation operates by assessing the development potential (or latent value) presents in the property which can be improved or developed so that the value will be increased by more that then expenditure. The residual value is known as the gross development value of the property less its gross development cost.

\section{Discount cash flow method}

With the adoption of the "Discounted cash flow method", the property is valued with the expectation that the owner will receive the revenue during the presumed operation period and to sell the property to a new purchaser thereafter. The future sale price is called the 
"reversion", and it is calculated by capitalizing the estimated net operating income for the year next to the end of the operation period. The sale proceeds will then be discounted, along with the revenue of the operating period to get an estimate of the present capital value.

Intangible assets valuation: business enterprises, trademarks, patented and unpatented technologies, copyrights, distribution agreements, goodwill, share options, bonds, convertible notes, operating rights. So maybe the intangible assets will be difficult to value; if the CEO pay more attention to it, it's really a hard work..

\section{VALUATION MODELS}

The purpose of a careful valuation analysis is to provide a disciplined procedure for arriving at a price. If the buyer offers too little, the target may resist and, because it is in play, seek to interest other bidders. If the price is too high, the premium might never be recovered from post merger synergies. These general principles are illustrated by the following simple model.

\section{The NVI model :}

Mergers increase value when the value of the combined firm is greater than the sum of the premerger values of the independent entities.

$$
\mathrm{NVI}=\mathrm{V}_{\mathrm{BT}}-\left(\mathrm{V}_{\mathrm{B}}+\mathrm{V}_{\mathrm{T}}\right)
$$

$\mathrm{NVI}=$ Net value increase

$\mathrm{V}=$ Value of bidder alone

$\mathrm{V}=$ Value of target alone

$\mathrm{V}=$ Value of firms combined

A simple example will illustrate. Company B (the bidder) has a current market value of $\$$ 40 millions. Company $\mathrm{T}$ (the target) has a current marker value of $\$ 40 \mathrm{million}$. The sum of the values as independent firm is, therefore, $\$ 80$. Assume that as Combined Company, synergies will increase the value to $\$ 100$. The amount of value created is $\$ 20$. Targets always receive a premium. If the bidder pays a premium of less than $\$ 20$, it will share in the value increase. If $B$ pays a premium larger than $\$ 20$, the value of the bidder will decline. If the bidder pays $\$ 50$ for the target, a premium of $25 \%$ has been paid to T. The value increase is shared equally. If B pays $\$ 60$ for $\mathrm{T}$, all gains go to the target $\mathrm{B}$ achieves no value increase. If B pays $\$ 70$ for $\mathrm{T}$, the value of B will decline to $\$ 30$.

\section{Capital Asset Pricing Model}

The most widely employed method used in calculating the cost of equity is the capital asset pricing model (CAPM). In CAPM, the required return on equity is risk-free return plus a risk component. For the economy as a whole, the risk-free rate would be related to the returns on U.S. government bonds. Because the discount factor used in valuation involves relatively long periods, the rates on relatively long -term bonds would be employed.

A model that describes the relationship between risk and expected return and that is used in the pricing of risky securities.

\section{CAPM model:}

$$
\mathrm{R}_{\mathrm{A}}=\mathrm{R}_{\mathrm{F}}+\operatorname{beta}^{*}\left(\mathrm{R}_{\mathrm{M}}-\mathrm{R}_{\mathrm{F}}\right)
$$

The general idea behind CAPM is that investors need to be compensated in two ways: time value of money and risk. The time value of money is represented by the risk-free (rf) rate in the 
formula and compensates the investors for placing money in any investment over a period of time. The other half of the formula represents risk and calculates the amount of compensation the investor needs for taking on additional risk. This is calculated by taking a risk measure (beta) that compares the returns of the asset to the market over a period of time and to the market premium (Rm-rf).

The CAPM says that the expected return of a security or a portfolio equals the rate on a riskfree security plus a risk premium. If this expected return does not meet or beat the required return, then the investment should not be undertaken. The security market line plots the results of the CAPM for all different risks (betas).

Using the CAPM model and the following assumptions, we can compute the expected return of a stock: if the risk-free rate is $3 \%$, the beta (risk measure) of the stock is 2 and the expected market return over the period is $10 \%$, the stock is expected to return $17 \%(3 \%+2(10 \%-3 \%))$.

\section{WACC Model}

A calculation of a firm's cost of capital in which each category of capital is proportionately weighted. All capital sources - common stock, preferred stock, bonds and any other long-term debt - are included in a WACC calculation.

WACC is calculated by multiplying the cost of each capital component by its proportional weight and then summing:

WACC Model:

$$
\mathrm{WACC}=(\mathrm{E} / \mathrm{V}) * \mathrm{Re}+(\mathrm{D} / \mathrm{V}) * \mathrm{Rd}^{*}\left(1-\mathrm{T}_{\mathrm{C}}\right)
$$

Where:

$\mathrm{Re}=$ cost of equity

$\mathrm{Rd}=$ cost of debt

$\mathrm{E}=$ market value of the firm's equity

$\mathrm{D}=$ market value of the firm's debt

$\mathrm{V}=\mathrm{E}+\mathrm{D}$

$\mathrm{E} / \mathrm{V}=$ percentage of financing that is equity

$\mathrm{D} / \mathrm{V}=$ percentage of financing that is debt

$\mathrm{Tc}=$ corporate tax rate

Broadly speaking, a company's assets are financed by either debt or equity. WACC is the average of the costs of these sources of financing, each of which is weighted by its respective use in the given situation. By taking a weighted average, we can see how much interest the company has to pay for every dollar it finances.

A firm's WACC is the overall required return on the firm as a whole and, as such, it is often used internally by company directors to determine the economic feasibility of expansionary opportunities and mergers. It is the appropriate discount rate to use for cash flows with risk that is similar to that of the overall firm.

\section{$\mathbf{M} \& \mathbf{M}$}

Modigliani-Miller Theorem (M\&M)

A financial theory stating that the market value of a firm is determined by its earning power and the risk of its underlying assets, and is independent of the way it chooses to finance its 
investments or distribute dividends. Remember, a firm can choose between three methods of financing: issuing shares, borrowing or spending profits (as opposed to dispersing them to shareholders in dividends). The theorem gets much more complicated, but the basic idea is that, under certain assumptions, it makes no difference whether a firm finances itself with debt or equity

In "Financial Innovations and Market Volatility" Merton Miller explains the concept using the following analogy:

"Think of the firm as a gigantic tub of whole milk. The farmer can sell the whole milk as is. Or he can separate out the cream and sell it at a considerably higher price than the whole milk would bring. (That's the analog of a firm selling low-yield and hence high-priced debt securities.) But, of course, what the farmer would have left would be skim milk with low butterfat content and that would sell for much less than whole milk. That corresponds to the levered equity. The $\mathrm{M}$ and $\mathrm{M}$ proposition says that if there were no costs of separation (and, of course, no government dairy-support programs), the cream plus the skim milk would bring the same price as the whole milk."

\section{Financial analysis}

\section{INFLUENTIAL FACTORS IN M\&A}

First of all, the financial analysis will be the most important, because is the most direct way to shows the net profit or loss incurred over a specific accounting period company's profit, the capital is gain or not, and is also a financial professional who has expertise in evaluating investment and puts together buy, sell and hold recommendations on securities. A financial statement that measures a company's financial performance over a specific accounting period. Financial performance is assessed by giving a summary of how the business incurred its revenues and expenses - due to both operating and non-operating activities, typically over a fiscal quarter or year. There are three major financial statements we must analysis: Income statement, Balance sheet and the statement of cash flows. Otherwise, we must analysis the reliable of these three financial statements.

\section{Income statement}

The income statement is divided into two parts: the operating and non-operating sections. The portion of the income statement that deals with operating items is interesting to investors and analysts alike, because this section discloses information about revenues and expenses that are a direct result of the regular business operations. For example, if a business creates sports equipment, then the operating items section would talk about the revenues and expenses involved with the production of sports equipment.

The non-operating items section discloses revenue and expense information about activities that are not tied directly to a company's regular operations. For example, if the sport equipment company sold a factory and some old plant equipment, then this information would be in the non-operating items section.

\section{Balance sheet}

Financial statement that summarizes a company's assets, liabilities and shareholders' equity at a specific point in time. These three balance sheet segments give investors an idea as to what the company owns and owes, as well as the amount invested by the shareholders.

The balance sheet must follow the following formula:

$$
\text { Assets }=\text { Liabilities }+ \text { Shareholders' Equity }
$$


Each of the three segments of the balance sheet will have many accounts within it that document the value of each. Accounts such as cash, inventory and property are on the asset side of the balance sheet, while on the liability side there are accounts such as accounts payable or long-term debt. The exact accounts on a balance sheet will differ by company and by industry, as there is no one set template that accurately accommodates for the differences between different types of businesses

It's called a balance sheet because the two sides balance out. This makes sense: a company has to pay for all the things it has (assets) by either borrowing money (liabilities) or getting it from shareholders (shareholders' equity).

The balance sheet is one of the most important pieces of financial information issued by a company. It is a snapshot of what a company owns and owes at that point in time. The income statement, on the other hand, shows how much revenue and profit a company has generated over a certain period. Neither statement is better than the other - rather, the financial statements are built to be used together to present a complete picture of a company's finances

\section{Cash flow statement}

One of the quarterly financial reports any publicly traded company is required to disclose to the SEC and the public. The document provides aggregate data regarding all cash inflows a company receives from both its ongoing operations and external investment sources, as well as all cash outflows that pay for business activities and investments during a given quarter.

Because public companies tend to use accrual accounting, the income statements they release each quarter may not necessarily reflect changes in their cash positions. For example, if a company lands a major contract, this contract would be recognized as revenue (and therefore income), but the company may not yet actually receive the cash from the contract until a later date. While the company may be earning a profit in the eyes of accountants (and paying income taxes on it), the company may, during the quarter, actually end up with less cash than when it started the quarter. Even profitable companies can fail to adequately manage their cash flow, which is why the cash flow statement is important: it helps investors see if a company is having trouble with cash.

Without analysis these three financial statement, we must see the reliability of these three statement, in most country, it has the GAAP, it's the simply the commonly accepted days of recording and reporting accounting information.

GAAP are imposed on companies so that investors have a minimum level of consistency in the financial statements they use when analyzing companies for investment purposes. GAAP cover such things as revenue recognition, balance sheet item classification and outstanding share measurements. Companies are expected to follow GAAP rules when reporting their financial data via financial statements. If a financial statement is not prepared using GAAP principles, be very wary.

\section{Economies of Scale}

The M\&A whether $1+1>2$, it's the economies of scale: the market, the competition, the input and so on these factors will be thinking about. The acquisition whether causes the increasing returns to scale. The increase in efficiency of production as the number of goods being produced increases. Typically, a company that achieves economies of scale lowers the average 
cost per unit through increased production since fixed costs are shared over an increased number of goods.

There are two types of economies of scale: External economies - the cost per unit depends on the size of the industry, not the firm. Internal economies - the cost per unit depends on size of the individual firm.

Economies of scale give big companies access to a larger market by allowing them to operate with greater geographical reach. For the more traditional (small to medium) companies, however, size does have its limits. After a point, an increase in size (output) actually causes an increase in production costs. This is called "diseconomies of scale".

Size and returns to scale The concepts of "economies of scale" and "synergies" have several dimensions that are worth clarifying. One aspect of scale economies comes from technical and engineering relations such as those between volume and surface area. In pipeline transportation, for example, scale economies are created between volume and surface area. In pipeline transportation, for example, scale economies are created because volume increases disproportionately to surface area.

Another natural economy of scale occurs in holding inventories when demand is subject to random influences. The statistical law of large numbers maintains that the larger the scale of operations is, the lower the required investment in inventories is in relation to the average quantity sold. Such improvements in inventory management often are facilitated by technological change and have been associated with mergers in grocery stores and other retail sectors.

Another important source of returns to scale is specialization. This was observed by Adam Smith in his famous example of producing pins. Firms of large size might be able to organize production into specialist groups that emphasize a single task. Such gains suggest one reason why growing industries often experience mergers.

Returns to scale can be distinguished from improved capacity utilization that spreads fixed costs over a larger number of units. In industries such as steel and autos, consolidating mergers have taken place to reduce industry capacity. Technological change is often a factor, as in the case of the tire industry following the development of radial tires, which last longer than their predecessors.

\section{long term and short term}

\section{a. Long-Term Investments}

An account on the asset side of a company's balance sheet that represents the investments that a company intends to hold for more than a year. They may include stocks, bonds, real estate and cash.

The long-term investments account differs largely from the short-term investments account in that the short-term investments will most likely be sold, whereas the long-term investments may never be sold

A common form of this type of investing occurs when company A invests largely in company B and gains significant influence over company B without having a majority of the voting shares. In this case, the purchase price would be shown as a long-term investment. 


\section{b. Short-Term Investments}

An account in the current assets section of a company's balance sheet. This account contains any investments that a company has made that will expire within one year. For the most part, these accounts contain stocks and bonds that can be liquidated fairly quickly.

Most companies in a strong cash position have a short-term investments account on the balance sheet. This means that a company can afford to invest excess cash in stocks and bonds to earn higher interest than what would be earned from a normal savings account.

Microsoft, which is always in a strong cash position, had short-term investments totaling approximately $\$ 32$ billion at the end of 2005 .

\section{Public goods and expected risk}

The influence factors including some uncertainly factors, such as public goods. Assumes that M\&A a product is the public goods, which provide the society service, the investor must weigh the matter seriously.

Expected risk evaluation is also named expected certainly risk or controllable risk. For a company, risk is the means inside and outside environment conditions uncertainly

Some decisions have to be carried out on the basis of expectations. So, in the real world, investment decision making involves taking a risk: the risk that the actual outcomes will almost certainly differ from what was expected. This chapter starts the examination of the problem of investment decision making in an uncertain world with the assertion that investors are averse to uncertainty-in other words they dislike risk. Therefore, in order to be persuaded be offered the expectation of a higher return from the investment as a reward, or as compensation for taking on the risk involved. Further, it follows that the greater the degree of uncertainty surrounding an investment's outcome, the greater will have to be the level of expected return in order to make the investment attractive to investors.

In a perfect world, the capital market would not display just a single rate of interest, but a whole continuum of interest rates-one for each level of risk: the higher the risk, the higher the interest rate, We could therefore adapt the NPV appraisal technique by using as the discount rate for any particular project appraisal, the perfect capital market discount tare which related tot that particular project's level of risk.

In such a way the discount rate would still correctly reflect the opportunity cost of undertaking the investment: the investment should only be undertaken if it produces a return that is at least equal to the return that could be obtained on the capital market, for similar level of risk.

Decisions are made all the time which affect public health and prioritize the use, possible misuse and/or protection of resources and biota. Risk Analysis is an approach and a set of tools for systematically comparing the social, economic, human health and other environmental costs and benefits of decision options. Risk Analysis includes problem definition, hazard and exposure assessment, risk characterization, risk communication and decisions affecting risk management. Risk Analysis can add transparency and inclusiveness to the decision-making process. Risk Analysis is multi-disciplinary, drawing on a range of basic scientific skills to generate data, and a wide array of other skills to communicate, evaluate, interpret, and act on the assessment. Risk Analysis is integrative. Risk Analysis provides an ideal framework for bridging among the research, teaching and outreach mandates at Cornell. 
The risk that a company will not have adequate cash flow to meet financial obligations. Financial risk is the additional risk a shareholder bears when a company uses debt in addition to equity financing. Companies that issue more debt instruments would have higher financial risk than companies financed mostly or entirely by equity.

\section{M\&A IN CHINA}

Merger and acquisition activity has increased dramatically in China developing over several years, gone are days when foreign companies wishing to invest in China were limited to Greenfield investments. Chinese regulatory regime has long been hostile to M\&A transactions. That regime is changing. However, both to accommodate these recent developments and to future stimulate foreign investment. They may now purchase operating Chinese businesses, spin-offs, and holding companies that were impossible only a few years ago.

Chinese World Trade Organization (WTO) accession will no doubt accelerate these changes. Nevertheless, the Chinese government will continue to have compelling political and economic reasons for maintaining controls in many economic sectors, and here the business and legal environments will continue to pose obstacles to M\&A transactions. These developments are not confined to foreign investors. Domestic Chinese companies are also merging and acquiring one another, and the more successful among them have begun to buy out foreign investors. The results of all of these developments in a rapidly expanding M\&A market in China.

The WTO has opened previously closed industry sectors to foreign investment, and is gradually lifting operating restrictions previously imposed on enterprises with foreign investment, and is gradually lifting operating restrictions previously imposed on enterprises with foreign investment, permitting greater access to Chinese domestic market. A mere ten years ago, such transactions were virtually unknown M\&A situation in China, they are now an increasingly common and important feature of Chinese economic landscape. The M\&A route now offer foreign investors a viable method of entering the Chinese market. With the continued strong growth of the Chinese economy, M\&A transactions offering immediate market access are becoming an increasingly attractive alternative to green field investment.

China had been not set any regulations in past few years, but now more and more foreign companies willing to invest here, so Chinese government has beginning set some rules for M\&A in China. Just because this, the rules could protect transactions, and investor.

Beijing has issued M\&A-related regulations including the provisional regulations on reforming state owned enterprises with foreign investment (effective Jan, 2003), the provisional regulations on foreign investors merging with and acquiring domestic enterprises (effective Apr 2003) and the provisional regulations on transfer of state ownership of Chinese enterprises (effective Feb, 2004).

These rules increase disclosure, transparency and certainty in the M\&A regulatory regime and seek to ensure that state assets are not sold or transferred at below what the PRC government regards as their proper value. They make it possible for mergers and acquisitions to be structured with more certainty. These regulations provide foreign investors with broader opportunities to acquire shares in State-owned enterprises and domestic enterprises and to acquire legal person shares of listed companies.

Government agencies play an important role in Chinese M\&A transactions. There is a higher level of government participation in $M \& A$ transactions in China than in typical in other 
jurisdictions. Despite the recent relaxation of foreign investment restrictions, pervasive approval requirements remain a distinctive feature of M\&A transactions in China.

In these transactions, PRC government agencies do not merely act as anti-trust or competition regulators. Their concern is not limited to the economic consequences of a transaction. They play a much broader role in reviewing and approving deal specific arrangements. In many M\&A transactions, government agencies act as both regulator and vendor, and will have social concerns that extend well beyond the commercial aspects of the transaction. The discretionary approvals required for an M\&A transaction are not mere formalities, and may take considerable effort to obtain. Understanding the applicable regulatory framework and the government's role in acquisition process is important to successfully concluding transactions in China.

\section{M\&A Regulations in China}

\section{FIE: (Foreign-invested Enterprises)}

The general regulatory framework applicable to foreign investment in China is also applicable to foreign related M\&A transactions. A foreign company is not permitted to directly operate a business in China. So it must do through FIE, which means foreign investment enterprise.

Though Chinese law is becoming more flexible, the forms of M\&A transactions, and accompanying procedures, authorized under Chinese law still differ in important respects from those in other jurisdictions. The available options generally depend on the result intended (merger, acquisition, or divestiture); whether the transaction involves other FIE or domestic Chinese companies: and the extent to which the transaction takes place within Chinese regulatory jurisdiction. Transactions involving mergers or acquisitions with wholly domestic Chinese companies present their own problems and merit separate discussion.

There are currently four types of FIE in China: sino-foreign equity joint ventures, sino-foreign cooperative joint ventures, wholly foreign-owned enterprises and foreign investment enterprises limited by shares. Although each type of FIE has its own distinctive features, FIE share many common characteristics and are generally limited liabilities companies.

Many foreign investors structure their holdings in China through intermediate offshore holding companies, often one for each FIE, precisely to permit this flexibility for subsequent transfers of their interests. So they found out the most effective way for foreign investors to avoid Chinese burdensome regulatory environment when transferring or acquiring Chinese business assets is to keep the entire transaction offshore. By using multiple intermediate offshore holding companies for different FIEs, corporate groups can also readily accomplish many forms of corporate restructuring without becoming enmeshed in the Chinese regulatory system.

The new regulations establish a basis for using conventional acquisition methods to acquire most types of enterprise in China. Regulations now permit foreign investors to engage in asset or equity acquisitions of FIEs, domestic enterprises, state-owned enterprises and listed companies. The range of permissible targets has been vastly expanded, but distinct regulatory regimes are applicable to acquisition of each type of entity. Such entity differentiated legal treatment remains fairly common in China. 


\section{Key PRC Government Agencies}

Several government agencies play a key role in M\&A transactions. The Ministry of Commerce and the State Development and Reform Commission ("SDRC") are the PRC government agencies with the primary responsibility for supervisory and approval authority over M\&A transactions. The SDRC is responsible for both approving the foreign investment project application and supervising the restructuring of state-own enterprises. These agencies will be involved in most M\&A transactions.

\section{M\&A Process in China}

\section{Asset Acquisitions}

An M\&A transaction may also be structured as an asset acquisition. In an asset acquisition, the acquirer may acquire select assets and liabilities of the target. There, consequently, is an opportunity to carve out unwanted assets and liabilities. Consideration is paid directly to the target, which maintains its separate legal existence. While time consuming, this method may be attractive given the difficulty of identifying with certainty the liabilities of PRC entities.

As a foreign company may not operate assets directly in China, a PRC acquisition vehicle is typically established simultaneously with the acquisition. The capital contributions made for the establishment of the acquisition vehicle are often used as consideration for the acquisition of the target assets.

Considerable government liaison work may be necessary for this type of transaction. Agreements with creditors are sometimes required. Arrangements with the target's workers will normally be examined during the approval process. In some cases, formal consultation with the target's workers on their settlement arrangement may be required. While the worker settlement issues are the responsibility of the target, their handing may impact the progress of the transaction. Customs approval and the payment of supplemental duty may be required if the acquired assets are under customs supervision.

\section{Mergers}

Statutory mergers are also sanctioned under PRC law. The provision on the merger and division of foreign investment enterprises provides a basis for merging FIEs and domestic enterprises. In a statutory merger, the acquiring entity succeeds to all of the assets and liabilities of the target by operation of law, while the existing investors' equity is transformed into merger consideration. A merger under PRC law may be structured in various ways. The target may be merged into the acquirer or a new entity can absorb both entities.

\section{Chinese company as the buyer}

In recent years, several of the more successful domestic Chinese companies have bought out foreign investors. Reportedly, some of these companies are interested in consolidating their positions before China enters the WTO. The Chinese buyers have simply seen attractive opportunities to take over the businesses of foreign investors who wish to divest themselves of their Chinese investment.

\section{Valuation}

Asset valuation is now required for all acquisitions of domestic assets, not simply for stateowned assets. The valuation must be undertaken by a licensed valuation organization, and separate regulations govern the valuation procedure. The valuation report will establish the reference price for the transaction. While the actual purchase price may vary from the valuation, government confirmation of the price may be required if the variance is too large. This requirement may complicate some transactions. 


\section{Financing}

Numerous obstacles complicate debt financing for M\&A transactions. FIEs are most often the acquisition vehicle but are subject to maximum leverage ratios that cap their borrowing ability. Existing FIEs may already have used up some of all of their authorized borrowing. Because procedures for pledging equity interests or registering security interests in assets are not fully developed, and enforcement of such interests in difficult at best. Banks are often unwilling to loan funds for acquisitions. Even cash payments can give rise to problems because of the inconvertibility of the RMB. If the Chinese party is required to make the payments in hard currency, it may be unable to obtain safe authorization for the conversion. When the foreign party is bringing new funds into China to make the acquisition, it must consider that, once converted to RMB and registered in the FIE's capital account, its funds may be difficult to convert back to hard currency and repatriate later.

\section{The future of M\&A in China}

China has made considerable advances in the last several years in developing a regulatory development have broadened the scope of permissible acquisitions and highlight China's commitment to honoring its WTO undertakings. These recent regulatory enactments establish the beginning of a viable framework for M\&A transactions in China. Both rang of targets and acquisition methods have been expanded and emerging market practices have been standardized and validated. It can be expected that more detailed implementing regulations to fill out the recently enacted general provisions will be issued in future. China should continue to attract the interest of foreign investors and M\&A transactions should become an increasingly viable method of accessing the Chinese market.

M\&A is getting more and more popular in this world; it happen everyday during two companies, even two centuries, so it has a close relationship with you and me. Without knowing about the events, we must know that reasons why some cases lost at last, what is the M\&A really mean? M\&A activities have important economic and business functions in enabling firms to adjust to changing environments and to enhance long term enterprise values. But combining organizations can pose considerable challenges causing M\&A failures. A widely held view is that about $67 \%$ of acquisitions do not earn the buyers' cost of capital.

Merger fail with lost of reasons: pay too much, overoptimistic expected synergies, no businesseconomic logic to the deal, culture clashes, basic industry problems such as overcapacity and so on , don't be surprise, even the company did not understand what they really boughtinternet, high tech. Maybe you don't believe it, but it's true, success or lose not only depends for one man-CEO, it has a close relationship with each person in that company.

Although this article haven't been taken an example in details, the discussion is influencing factors effect the M\&A, it's necessary to point out why some company lost their target. If the company will take such an action, this article will help you.

In the 21 century, there are more and more Chinese companies willing to go abroad, to develop their business。For Chinese companies, small company join into big company is the shortcut method; it can get the core technology, the brand and the market force. Set up a new brand is more difficult, some brands have been well-known, like P\&G, IBM, and they are famous in the world. A small company join into the big company is a quick way. But Chinese companies lack of international management experience, how to manage such a big international corporation, even the complex systems, know less about it. So it will bring on some problems, like the 
financial risk, including the M\&A capital, the debt, and the service fee, these will make the company going worse.

These years some M\&A cases in China become successful, like Lenovo and IBM. On $8^{\text {th }}$ December 2004, Lenovo and IBM signed an important contract. The contract confirmed the Lenovo group ( Lenovo) was going to M\&A with IBM Personal Computer Department (PCD). This will make Lenovo become a competitive international corporation with the well know brand name, a variety of innovative products and the leading research development in the IT market.

This case not only effects two companies, meanwhile it effects the whole IT industry, use the IBM's brand, management, and other advantages factors makes it successful. This case is the apotheosis; it has the useful meaning in the M\&A history of China. The real international stratagem and the brand internationalization will take the value chain overspread other countries. More and more companies in different country will know this brand, knowing about this industry, like it and buy it. The real internationalization must be investment abroad, sell out, cut cost, and make the force of example, set up a distribution market.

For Chinese corporation, it will work hard on three ways: first of all, bring up the corecompetitiveness. Price predominance can not be the core-competitiveness in Chinese corporation, this predominance is flimsiness, and also low price is getting limited, when customers know nothing about your brand or don't accept it, it could not be respected.

In the next place, Chinese corporation must set up an international management systems. The society development depends on the best management systems. Chinese may pay more attention to it.

The last is human recourse will become globalization Manage. Human recourse becomes a new topic in the world. How to manage people has a close relationship in the company.

So now Chinese corporation will to go abroad, M\&A happens everyday in the world. Face such the problems it will be success soon.

\section{Reference}

Steve Lumby , Chris Jones . Fundamentals of Investment Appraisal, 2001 The Lumby Family Partnership

Robert J. Borghese \& Paul F. Borgese. M\&A from planning to integration, Copublished with Association for Financial professionals 2001

Van Horne, J. C. , Wachowica, J. M. Fundamentals of Financial Management, translated by H. Guo and L.Xu, .Beijing Economics Press 1998.10

J. Fred Weston Case in Dynamic Finance: Mergers and Restructuring, translated byJ. Zhang, Renmin University Press, 2004

J. Fred Weston, Mark L. Motchell , J. Harold Mulherin Takeovers, Restructuring, and Corporate Governance, Pearson Prentice Hall, 2004

Donald Depamphilis Mergers, Acquisitions, and other Restructuring Activities, translated by RRHuang and Y. Luo, Machinery Industry Press, 2004

Steven E. Landsburg Price Theory and Applications, Machinery press 2002

Michael Keenan, Lawrence J. White Mergers \& Acquisitions, New York University Harvard business review on mergers and acquisitions, Boston: Harvard Business School Pub. Corp., c2001

Mansour Javidan, Malden, Mergers and acquisitions: creating integrative knowledge, ed. in Amy L. Pablo, MA: Blackwell, 2004. 
Chen, T., \& Pan, X. (2019). An Exploration to the Factors Affecting China's Mergers and Acquisitions Costs. Archives of Business Research, 7(1), 1840.

William F. Sharpe, Gordon J. Alexander, Jeffery V. Bailey Investments Prentice Hall.

P.S. Sudarsanam Merger and Acquisition, translated by CITIC Press, 1998 